Jurnal Biologi dan Pembelajarannya, Vol 6 No 2, Oktober 2019. Pp: 12-14

e-ISSN: $2406-8659$

\title{
PENGARUH VARIASI LAMA PENUNDAAN PEMERIKSAAN TERHADAP ENUMERASI BAKTERI PADA URIN PENDERITA INFEKSI SALURAN KEMIH (ISK)
}

\author{
Inayah Fitri $^{{ }^{*}}$, Triffit Imasari $^{2}$, Diva Nadia Wulantika ${ }^{3}$ \\ ${ }^{1}$ Prodi S1 Biologi, FMIPA, Universitas Billfath Lamongan \\ ${ }^{2}$ Prodi D4 TLM, FSTA, IIK Bhakti Wiyata Kediri \\ ${ }^{3}$ Laboratorium Bakteriologi, IIK Bhakti Wiyata Kediri \\ Email: f.inayah89@gmail.com
}

\begin{abstract}
Abstrak
Hitung jumlah bakteri merupakan gold standard untuk konfirmasi ISK. Hitung jumlah bakteri harus menggunakan urin segar, karena penggunaan urin yang telah ditunda dapat menyebabkan peningkatan bakteri. Tujuan: untuk mengetahui pengaruh variasi lama penundaan pemeriksaan urin terhadap jumlah bakteri. Metode: inokulasi di media CLED. Hasil: penundaan 0 jam $=4.5 \times 10^{4} ; 1.5$ jam $=5.5 \times 10^{4} ; 4$ jam $=5.9 \times 10^{4}$; dan 6 jam $=1.4 \times 10^{5} \mathrm{CFU} / \mathrm{ml}$.
\end{abstract}

Kata kunci- ISK, Jumlah bakteri, Penundaan pemeriksaan

\section{PENDAHULUAN}

Infeksi Saluran Kemih (ISK) merupakan kontaminasi pada saluran kemih yaitu ginjal, ureter, kandung kemih serta uretra yang disebabkan ketika virulensi meningkat, pertahanan inang menurun, adanya inokulasi dan kolonisasi bakteri [1][2]. Bakteri patogen pada penderita ISK yaitu Escherichia coli, Proteus sp., Klebsiella sp., Staphylococcus aureus, Enterococcus faecalis, dan Streptococci grup B[3]. Berdasarkan data Centers for Disease Control and Prevention (CDC), (2011), sebanyak 8,6 juta orang membutuhkan rawat jalan yang disebabkan oleh ISK [4]. Angka kejadikan ISK di Indonesia masih tergolong tinggi, hal ini ditunjukkan oleh survei demografi Depkes RI (2014), bahwa penderita ISK mencapai 90 - 100 kasus tiap 100.000 penduduk pertahun $[5]$.

Diagnosa penyakit ISK sangat diperlukan untuk menentukan langkah dalam pengobatan. Hitung jumlah bakteri merupakan gold standard untuk konfirmasi ISK [6]. Hasil hitung jumlah bakteri pada urin digunakan untuk menentukan derajat keparahan ISK yaitu keparahan ringan berjumlah $10^{3} \mathrm{CFU} / \mathrm{ml}$, sedang sekitar $10^{4}$ $\mathrm{CFU} / \mathrm{ml}$, dan berat jika mencapai $10^{5} \mathrm{CFU} / \mathrm{ml}$ [7].

Pada beberapa rumah sakit, sampel urin seringkali dikirim ke laboratorium dalam kondisi yang tidak segar, padahal pemeriksaan bakteri pada urin harus segera dilaksanakan, karena penundaan pemeriksaan menyebabkan perkembangbiakan bakteri, sehingga koloni yang tumbuh tidak menunjukkan jumlah bakteri sebenarnya dalam urin pada saat pengambilan [6]. Pada penelitian Sirait (2017), menunjukkan bakteri berjumlah $7,5 \times 10^{4} \mathrm{CFU} / \mathrm{ml}$ dipenundaan 6 jam, saat penundaan 12 jam terjadi peningkatan $1,2 \times 10^{5} \mathrm{CFU} / \mathrm{ml}$, akan tetapi saat penundaan 18 dan 24 jam mengalami penurunan menjadi $8,0 \times 10^{4} \mathrm{CFU} / \mathrm{ml}$ dan $7,8 \times 10^{4}$ $\mathrm{CFU} / \mathrm{ml}$ [8]. Berdasarkan uraian di atas, maka peneliti tertarik untuk melakukan penelitian yang bertujuan untuk mengetahui pengaruh variasi lama penundaan pemeriksaan urin terhadap jumlah bakteri.

\section{METODE PENELITIAN}

Penelitian ini merupakan eksperimental yang disusun secara rancangan acak lengkap dengan satu faktor perlakuan dan enam kali ulangan. Faktor perlakuan penelitian yaitu penundaan pemeriksaan sampel selama 0 ; 1,5; 4; dan 6 jam. Prosedur kerja dalam penelitian meliputi pembuatan media CLED, pengambilan sampel menggunakan metode urin porsi tengah [9] dan enumerasi bakteri pada urin yaitu jumlah koloni yang tumbuh di media dikalikan dengan faktor sengkelit terkalibrasi (100 CFU/ml untuk sengkelit $10 \mu \mathrm{L}$ dan $1000 \mathrm{CFU} / \mathrm{ml}$ untuk sengkelit $1 \mu \mathrm{L}$ ) [10]. Pengambilan sampel urin penderita ISK dilakukan di Laboratorium Rumah Sakit Muhammadiyah Ahmad Dahlan Kediri. Pembuatan media serta enumerasi bakteri dilakukan di Laboratorium Bakteriologi IIK Bhakti Wiyata Kediri. Penelitian dilaksanakan pada bulan Mei 2019.

Alat yang digunakan dalam penelitian yaitu timbangan analitik, erlenmayer, petri disk dissposible, oven, colony counter, gelas ukur, spatel, pot urin, sengkelit terkalibrasi, inkas, dan autoclave. Bahan yang digunakan dalam penelitian yaitu spesimen urin penderita ISK, aquadest, media CLED, aluminum foil, alkohol $70 \%$, dan spirtus. 
Jurnal Biologi dan Pembelajarannya, Vol 6 No 2, Oktober 2019. Pp: 12-14

e-ISSN: $2406-8659$

\section{HASIL DAN PEMBAHASAN}

Hasil perhitungan jumlah bakteri pada setiap penundaan ke- $0 ; 1,5 ; 4$; dan 6 jam menunjukkan peningkatan jumlah bakteri. Rata - rata jumlah tertinggi pada penundaan ke 6 jam yaitu sebesar $1,4 \times 10^{5}$ $\mathrm{CFU} / \mathrm{ml}$. Untuk mengetahui perbedaan jumlah keempat perlakuan penundaan, maka dilakukan perhitungan nilai rata - rata yang akan disajikan pada Tabel 1.

Tabel 1. Hitung jumlah koloni bakteri pada penundaan pemeriksaan

\begin{tabular}{lll}
\hline No & Penundaan Ke-.... jam & Rata-Rata Jumlah Koloni (CFU/mL) \pm STDV \\
\hline 1 & 0 & $4,5 \times 10^{4} \pm 28,12$ \\
\hline 2 & 1,5 & $5,5 \times 10^{4} \pm 18,35$ \\
\hline 3 & 4 & $5,9 \times 10^{4} \pm 24,04$ \\
\hline 4 & 6 & $1,4 \times 10^{5} \pm 53,35$ \\
\hline
\end{tabular}

Untuk mengetahui pengaruh penundaan pemeriksaan terhadap jumlah koloni bakteri, maka dari rata rata tersebut dilakukan analisis data statistik. Uji yang digunakan yaitu Kruskal wallis dan uji lanjutan Mann whitney. Pada Tabel 2 merupakan hasil uji Kruskal wallis, menunjukkan bahwa nilai signifikansi tiap variasi penundaan berpengaruh terhadap rata - rata jumlah koloni, hal ini dikarenakan memiliki nilai Asymp.sig $(0,005)<0,05$. Kemudian digunakan uji mann whitney sebagai uji lanjut dari uji kruskal wallis. Pada Tabel 3 merupakan hasil uji Mann whitney, menunjukkan adanya perbedaan nyata pada penundaan ke 6 jam.

Tabel 2. Uji Kruskal wallis

\begin{tabular}{ll}
\hline Chi-Square & 7,248 \\
\hline Df & 6 \\
\hline Asymp. Sig &, 005 \\
\hline
\end{tabular}

Tabel 3. Uji Mann whitney

\begin{tabular}{lllll}
\hline Penundaan & Kontrol & 1,5 jam & 4 jam & 6 jam \\
\hline Kontrol & - & $\times$ & $\times$ & $\checkmark$ \\
\hline 1,5 jam & - & - & $\times$ & $\checkmark$ \\
\hline
\end{tabular}

Sampel urin umumnya tidak boleh dilakukan penundaan pemeriksaan, namun seringkali pada suatu instansi rumah sakit ataupun laboratorium sampel urin dilakukan penundaan pemeriksaan. Adapun beberapa faktor seperti kurangnya tenaga kerja medis, banyaknya sampel, kurangnya fasilitas yang tersedia sehingga memungkinkan untuk melakukan penundaan pemeriksaan [11].

Dari hasil penelitian menunjukkan bahwa sampel urin tidak dapat dilakukan penundaan pemeriksaan dalam waktu 6 jam. Pada penundaan 6 jam menunjukkan pertumbuhan bakteri yang meningkat secara signifikan. Hal ini sesuai dengan kurva pertumbuhan bakteri yaitu bakteri yang diinokulasikan pada suatu medium akan beradaptasi dan melakukan penyesuaian diri dengan lingkungan baru, bakteri kemudian akan memperbanyak diri dengan kecepatan konstan. Hasil penelitian menunjukkan bakteri berada dalam fase eksponensial. Pada fase eksponensial bakteri tumbuh dan membelah dengan kecepatan maksimum. Sel baru akan terbentuk dengan laju konstan serta massa bertambah secara eksponensial [12]. Pada penundaan 1,5 jam dan 4 jam bakteri berada pada fase lag, yaitu fase bakteri beradaptasi dan melakukan penyesuaian pada lingkungan baru. Pada fase lag lama bakteri beradaptasi dipengaruhi oleh komposisi media, pH, suhu, jumlah sel pada inokulum awal dan sifat fisiologis mikroorganisme pada media sebelumnya. Apabila dilakukan penundaan lebih dari 6 jam maka dapat menjadikan hasil positif palsu atau hasil tidak sesuai dengan kondisi pasien dan akan berdampak pada kondisi pasien selanjutnya. Hal ini sesuai dengan penelitian Sirait (2017) pemeriksaan yang dilakukan penundaan dengan sampel urin yang disimpan pada coolbox mengalami 
Jurnal Biologi dan Pembelajarannya, Vol 6 No 2, Oktober 2019. Pp: 12-14

e-ISSN: $2406-8659$

peningkatan pada waktu penundaan 6 jam yaitu $75.950 \mathrm{CFU} / \mathrm{ml}$, pada waktu penundaan 12 jam 128.000 $\mathrm{CFU} / \mathrm{ml}[8]$.

Peningkatan jumlah bakteri dapat dipengaruhi karena beberapa faktor seperti yang $\mathrm{pH}$, karbon dioksida, oksigen, suhu, tekanan osmosis, dan nutrisi. Dari beberapa faktor tersebut yang paling menonjol mempengaruhi pertumbuhan bakteri dalam urin adalah nutrisi. Di dalam urin terdapat nutrisi yang mendukung pertumbuhan bakteri seperti hasil sisa metabolisme tubuh yaitu garam terlarut (natrium), mengandung asam organik (asam bikarbonat, asam lemak, asam laktat, asam karbonat), mengandung asam anorganik (sulfur, belerang, dan fosfor), mengandung sisa-sisa elektrolit (fosfat, iodium, magnesium, kalsium, kalium, oksalat, ion hidrogen, amoniak, dan bikarbonat), dan mengandung garam-garam terlarut (natrium dan klorida) yang menjadi nutrisi bakteri untuk tumbuh [13]. Faktor lain yang dapat mempengaruhi pertumbuhan bakteri adalah suhu, urin memiliki suhu normal yaitu $32-38^{\circ} \mathrm{C}$. Metabolisme bakteri dapat dipengaruhi oleh suhu, semakin meningkat bakteri yang tumbuh menunjukkan semakin cepatnya metabolisme dari bakteri. Bakteri memiliki suhu optimum dan minimum dalam masa pertumbuhannya. Pada masing-masing bakteri memiliki suhu optimum dan minimum yang berbeda-beda untuk mendukung masa pertumbuhannya. Bakteri di dalam urin sebagian besar merupakan bakteri enterik yaitu bakteri yang dapat tumbuh dengan suhu optimum $30-37^{\circ} \mathrm{C}$ dan suhu minimum $5-10^{\circ} \mathrm{C}[3]$.

\section{SIMPULAN}

Kesimpulan dalam penelitian yaitu terdapat pengaruh antara variasi penundaan pemeriksaan terhadap rata - rata jumlah koloni bakteri dalam sampel urin penderita ISK. Perbedaan nyata terlihat pada variasi penundaan pemeriksaan ke-6 jam.

Saran bagi peneliti selanjutnya yaitu dapat melakukan penundaan pemeriksaan hingga didapatkan kurva pertumbuhan bakteri; mencari hubungan antara pemeriksaan yang dilakukan untuk mendiagnosa pasien ISK; dan melihat perbandingan jumlah bakteri pada sampel urin yang diberi pengawet.

\section{SARAN}

\section{UCAPAN TERIMA KASIH}

Laboratorium Rumah Sakit Muhammadiyah Ahmad Dahlan Kediri sebagai tempat pengambilan sampel urin penderita ISK.

\section{DAFTAR PUSTAKA}

[1] Brusch, J.L., Cunha, B.A., Tessier J.M., Bavaro M. F., 2016. Sistitis in Females. Drugs and Disease.

[2] Ikatan Ahli Urologi Indonesia. 2015. Guideline Penatalaksanaan Infeksi Saluran Kemih dan Genitalia Pria, edisi ke-2.

[3] Krihariyani, D. 2010. Pengaruh Penyimpanan Urin Kultur pada Suhu 2ㅇ-C 8 ㄷ Selama Lebih Dari 24 jam Terhadap Pertumbuhan Bakteri. Jurnal Penelitian Kesehatan Forikes, vol 1, no.2 April 2010.

[4] Centers for Disease Control and Prevention (CDC). 2011. Ambulatory Medical Care Utilization Estimates for 2007. Edisi 13. U.S. Department of Health and Human Services. Washington.

[5] Departemen Kesehatan Republik Indonesia (Depkes RI). 2014. Survei Demografi dan Kesehatan Indonesia. Depkes RI: Jakarta.

[6] Schiemann, Guido., Gagyor, Ildiko., Pradier, Eva., Bleidorn, Jutta. 2012. Resistance Profiles of Urinary Tract Infection in General Practice-An Observational Study. BMC Urology, 12:33.

[7] Grabe, M., Bartoletti, R., Bjerklund, J. 2015. Guidelines on Urological Infections. Europa: European Association of Urology.

[8] Sirait, R. 2017. Penundaan Pemeriksaan Kulture Urin Pasien dengan Penyimpanan Menggunakan Coolbox pada Pertumbuhan Bakteri di RSUP dr. Kariadi Semarang. KTI, Fakultas Keperawatan dan Kesehatan. Universitas Muhammadiyah Semarang.

[9] Peraturan Menteri Kesehatan Republik Indonesia Nomor 43 Tahun 2013. 2013. Penyelenggaraan Laboratorium yang Baik. Berita Negara Republik Indonesia Tahun 2013 Nomor 1216. Jakarta.

[10] Vandepite, J., Verhaegen, J., Engbaek, K., Rohner, P., Poit, P., Heuck, C.C. 2010. Prosedur Laboratorium Dasar untuk Bakteriologi Klinis. Jakarta: EGC.

[11] Rosita, L.. 2011. Pengaruh Penundaan Waktu terhadap hasil Urinalisis. Skripsi. Departemen Patologi Klinik Fakultas Kedokteran. Universitas Islam Indonesia Yogyakarta. 
Jurnal Biologi dan Pembelajarannya, Vol 6 No 2, Oktober 2019. Pp: 12-14 e-ISSN: $2406-8659$

[12] Jawetz., M., \& Adelberg. 2013. Mikrobiologi Kedokteran Ed.25. Jakarta: EGC.

[13] Gandasoebrata, R. 2007. Penelitian Laboratorium Klinik, Edisi 13. Jakarta: Dian Rakyat. 